\title{
O JUIZ CONSTITUCIONAL ME REPRESENTA? O Supremo Tribunal Federal e a representaçáo argumentativa
}

\section{Luis Felipe Miguel (1)}

(D) https://orcid.org/0000-0002-0420-6327

\section{Daniel Bogéa}

(D) https://orcid.org/0000-0003-0486-9427

(1) Universidade de Brasília (UnB), Brasília - DF, Brasil.

E-mail: luisfelipemiguel@gmail.com

(2) Università degli studi di Genova, Gênova, Itália.

E-mail: danielvbs@gmail.com

DOI: $10.1590 / 3510402 / 2020$
Já há algumas décadas, os estudiosos brasileiros reconhecem a centralidade do Supremo Tribunal Federal nas disputas políticas do país. Se, em outros tempos, ele era tratado como um "outro desconhecido” (Baleeiro, 1968), hoje é reconhecido como protagonista, seja por críticos, seja por entusiastas de seu novo papel (Falcão e Oliveira, 2013). Para tal mudança, concorreram três fatores, em parte ligados entre si. Houve uma ampliação da pesquisa sobre a ação do Poder Judiciário, que se tornou uma área importante dentro da Ciência Política brasileira (entre os estudos fundadores, cf. Arantes, 1997; Castro, 1997; Vianna et al., 1999; Vianna, 2002). Houve a expansão dos poderes do STF, especialmente a partir da Constituição de 1988. E houve a emergência dos fenômenos paralelos da "judicialização da política" (a transferência da solução de querelas entre agentes

Artigo recebido em: 03/08/2018

Aprovado em: 24/11/2019 políticos do processo eleitoral e do parlamento para os tribunais) e do "ativismo judiciário"2 (em que as cortes intervêm vigorosamente na agenda política, adotando reinterpretaçóes de regras que na prática equivalem a nova produção legislativa). No processo, os ministros do Supremo passaram a ser reconhecidos pela imprensa e mesmo pelo público em geral como atores-chave da política brasileira. Em uma exposição que causa espanto a quem se atém ao ideário do juiz de perfil discreto que "só fala pelos autos", no Brasil dos últimos anos, provavelmente não se passa uma semana sem que as páginas dos jornais ostentem uma análise de conjuntura por algum integrante das cortes superiores.

Esse crescente protagonismo torna mais aguda uma questão que, na verdade, acompanha sempre a posição do Poder Judiciário em ordenamentos políticos que se querem democráticos. Por que um regime fundado na ideia da soberania do povo conferiria o poder de tomar decisóes fundamentais a um punhado 
de homens e (menos) mulheres que não contam com a legitimação do voto popular? A questão se torna tanto mais premente quanto mais os tribunais se afastam da imagem de meros aplicadores da letra da lei a casos concretos.

Uma resposta clássica à questão vem da fundamentação normativa dada ao arranjo constitucional dos Estados Unidos - que, por sua vez, é inspiração central para nossa própria separação de poderes. Por um lado, uma vez que, para seu bom funcionamento, o controle mútuo entre os poderes depende de que eles estejam ancorados em fontes diversas de legitimidade, o caráter não eletivo do Judiciário torna-se parte da soluçáo, não do problema. Por outro lado, as cortes cumpririam papel decisivo na tarefa de impedir a "tirania da maioria" e garantir a estabilidade de normas que, de outro modo, seriam alteradas conforme soprassem os ventos da opinião predominante. Ambos os argumentos encontram curso já nos escritos federalistas (Hamilton, Madison, Jay, 1990 [1788]) e, no século XIX, ecoam em obras como a de Alexis de Tocqueville (1992 [1835-1840]).

Outra resposta é mais recente e, à primeira vista, surpreende. A despeito da ausência de autorização popular, o juiz seria um representante, com legitimidade democrática tão sólida quanto a dos funcionários eleitos do Legislativo ou do Executivo. Trata-se de uma apropriação, no âmbito do Judiciário, de discussões recentes na teoria da representação política. Face ao desencanto crescente com a representação nascida dos processos eleitorais e à desesperança quanto ao funcionamento dos mecanismos de autorização e accountability associados a eles, diversos autores têm enfatizado a existência de "múltiplas formas de representar”, tornando facultativas não apenas a eleição, mas também a autorização dos representados e a accountability dos representantes em relação ao eleitorado. ${ }^{3}$ Os juízes seriam, então, um caso particular - precoce e com poder institucional - de representantes não eleitorais.

Parte desse movimento, seja na teoria da representação em geral, seja em sua aplicação ao Judiciário, provém de visões alinhadas ao ideal democrático deliberativo. Já no final do século passado, teóricos deliberativos com maior inclinação elitista indicavam que o debate racional e desinteressado, inviável para a sociedade mais ampla, seria possível caso as decisões fossem atribuídas a pequenos colegiados virtuosos - e as cortes supremas são o primeiro exemplo (cf. Bell, 1999). Mas, como a noção predominante de representação ainda remetia ao vínculo expresso entre representantes e representados, ela não era evocada na discussão. Somente após a disseminação da noção de representação autoinstituída é que se torna possível dar tal passo. As cortes exerceriam um papel representativo, seja de forma contramajoritária, na defesa de interesses minoritários que de outra forma seriam esmagados, seja mesmo interpretando vontades majoritárias que, por um motivo ou outro, os organismos representativos tradicionais não são capazes de elaborar. Assim, sustenta o teórico do direito Robert Alexy, a partir de um ideal deliberacionista, um tribunal constitucional se legitima democraticamente ao exercer a representação argumentativa do povo.

Com isso não se deve pensar, como os teóricos da Organschaft citados por Pitkin (1967, pp. 39-42), que o juiz representa a vontade social de que seja cumprida uma determinada função especializada, no caso a imposiçáo da lei, assim como um carteiro, por exemplo, representa o desejo coletivo de que a correspondência seja entregue. $\mathrm{O}$ que caracteriza a tese da representação argumentativa é o fato de que as cortes constitucionais exercem seu papel representativo justamente porque extrapolam o que seria o mero trabalho técnico de aplicação da norma ao caso concreto.

Nosso objetivo neste artigo é colocar em escrutínio a ideia de um tribunal judicial como representante argumentativo do povo. Ao enfrentar esse debate teórico, poderemos analisar criticamente a forma pela qual o argumento tem sido incorporado ao repertório retórico de alguns juízes do Supremo Tribunal Federal em seus votos e em outras formas de intervenção pública, projetando-se como representantes do povo e, assim, reivindicando um papel de maior destaque no processo de transformação social. Desse modo, eles passam a ocupar um espaço que usualmente é conferido a instituiçóes dotadas de pedigree popular mais inequívoco. Ao indagar se "o juiz constitucional me representa”, 4 pretendemos jogar luz sobre os limites e ônus institucionais trazidos pela tese da representação argumentativa. Podemos, assim, 
explicitar as fragilidades dessa abordagem para dar sentido à atuação do Supremo na combalida democracia brasileira.

A primeira parte do artigo discute a expansão da ideia de representação para além dos limites eleitorais e a tentativa de associação desse processo à ascensão de cortes constitucionais. Na segunda parte, discutimos a ideia de representação argumentativa, sobretudo na versão de Robert Alexy, que bebe na fonte de teorias da democracia deliberativa e avança sobre a noção de que a representação supera os limites do voto e pode se dar a partir de modelos de argumentação racional. $\mathrm{Na}$ sequência, pontuamos como a tese da representação argumentativa vem alcançando projeção em votos e escritos de juízes do STF. Não se trata de fazer uma mensuração para postular prevalência ou não desse discurso entre os magistrados, mas de observar como ele entrou no repertório de argumentos legitimadores de sua ação. Por fim, propomos a pergunta sobre como (e se) um juiz constitucional nos representa para enfatizar os problemas na utilização da ideia de representação para uma justificação democrática da atuação do STF.

Nosso propósito é demonstrar que a própria articulação teórica que postula a representatividade argumentativa de cortes constitucionais padece de fragilidades insuperáveis associadas à crença desmedida no potencial deliberativo de tribunais, à ausência de mecanismos de aproximação entre pretensos representantes e seus representados e à ausência de mecanismos efetivos de accountability. Além disso, buscamos indicar o problema adicional relacionado ao modo como esse argumento vem sendo absorvido pela retórica de alguns ministros do Supremo, servindo de blindagem discursiva para decisóes politicamente salientes e controversas. Reforçamos, assim, o caráter elitista dessa tentativa, que exacerba o isolamento da corte frente aos seus ditos representados e firma a distância crescente do núcleo por definição democrático da soberania enquanto exercício popular do poder político.

\section{Representação para além das eleiçóes}

A associação entre democracia e representação eleitoral, que hoje tende a ser encarada como evidente, é fruto de uma longa história. Ainda na metade do século XVIII, Montesquieu (1951 [1748]) afirmava, como que reiterando algo conhecido por todos, que a eleição era característica da república aristocrática, ao passo que a república democrática preencheria os cargos públicos por meio de sorteio. As eleições das democracias liberais contemporâneas não são idênticas àquelas das repúblicas italianas em que pensava Montesquieu, mas permanecem marcadas por uma ambiguidade quanto a seu componente popular. Como observou Bernard Manin (1997), se o recrutamento dos votantes é democrático, na medida em que incorpora a todos (ainda que seja um "todos" historicamente situado), a seleção dos eleitos guarda um inegável caráter aristocrático. É da natureza da seleção eleitoral que os vitoriosos o sejam porque foram aceitos pela opiniáo predominante como portadores de qualidades especiais, que os credenciam ao exercício do poder. E, nas sociedades reais, diversos fatores enviesam o processo e homogeneízam o grupo dos eleitos em termos de classe social e renda, nível de escolaridade, raça e cor, gênero e faixa etária.

As características dos representantes seriam menos importantes caso se julgasse que os mecanismos de accountability, que deveriam garantir sua vinculação perene às vontades dos representados, funcionassem bem. Não é o caso. A constatação da distância entre eleitores e eleitos levou as teorias da representação à busca por novos caminhos. A aposta na revalorização da representação descritiva, sob o rótulo de "política de presença” (Phillips, 1995), preconizava uma maior semelhança de características entre os constituintes e seus porta-vozes. Motivou, em particular, a adoção de cotas para grupos sociais em desvantagem garantirem acesso aos espaços de decisão hoje vedados a eles. Na direção contrária, a chamada "representação autoinstituída" despreza a similitude entre os representantes e os representados; em seu lugar, valoriza o acesso de alguns às esferas de decisão e sua vontade subjetiva de falar em nome de outros (Saward, 2010). ${ }^{5}$

No Brasil, a teorização sobre representação autoinstituída teve como foco primário os novos espaços, ditos "participativos", que o Estado abriu à sociedade civil, na onda democratizadora que se seguiu à promulgação da Constituição de 1988, como conselhos e conferências de políticas governamentais. ${ }^{6}$ Nesses espaços, ingressaram dirigentes de associaçóes 
civis e organizações não governamentais, na condição de representantes de um público amplo - que, em geral, não tinha nem ciência de que estava sendo representado, muitos menos concedida sua autorização. Tornava-se necessário, portanto, estabelecer novos parâmetros que justificassem a legitimidade da reivindicação representativa feita por tais atores (cf. Gurza Lavalle, Houtzager e Castello, 2006; Avritzer, 2007; Almeida, 2015; para críticas, Miguel, 2014; 2017, cap. 2; 2018, cap. 8).

Assim, as cortes judiciárias, em particular as constitucionais, são incorporadas num movimento de alargamento conceitual da noção de representação política que era voltado primariamente para outras organizaçōes. Como sintetizou Pogrebinschi, a démarche depende da "atualização semântica" - que, acrescentamos nós, talvez fosse mais bem definida como "redefinição completa" - do tripé normativo que sustentaria a noção corrente de representação política. Atualização, portanto, “a) do fundamento da representação, a delegação; b) de seu corolário e condição de validade, a revogação; c) de sua principal condição de legitimidade, a eleição" (Pogrebinschi, 2013, p. 167). De fato, ao contrário do parlamento ou da chefia dos poderes executivos, um órgão como o STF não possui caráter delegado, dispóe de mandatos cuja revogação não está condicionada por mecanismos de responsabilização (há apenas uma idade máxima fixada pelo texto constitucional) e prescindem de eleição popular.

A defesa da representação por tribunais se apoia em uma premissa pragmática, que se concentra essencialmente na aferição de consequências. O que torna uma instituição representativa é dado pela experiência, já que o significado de um conceito "apenas pode ser conhecido através de suas consequências práticas" (Pogrebinschi, 2013, p. 176). Essa volatilidade conceitual, que é própria ao pragmatismo, gera no entanto uma incerteza quanto ao que determina que uma relação possa ou não ser considerada integrante da categoria "representação". Se, como por vezes parece ser, as consequências legítimas são aquelas que se assemelham às alcançadas pela representação de tipo tradicional, fica posto em xeque o propósito de promover o deslocamento do conceito. Impugnado tal critério, não sobra qualquer outro que permita entender por que determinadas consequências são ou não aceitas como representativas.

Pogrebinschi argumenta que a representação efetivada pelas cortes constitucionais possui um caráter especificamente pró-minoritário. $\mathrm{O}$ processo eleitoral trabalha contra as minorias, que estâo fadadas à derrota e não conseguem impor seus interesses por meio dele. O locus para representação de minorias que não alcançam espaço nas instituiçóes eleitorais deslocar-se-ia para as instituições judiciais; estaríamos diante de um salutar e inovador experimentalismo institucional. Um tribunal poderia, assim, "não apenas dar voz a tais demandas [dos grupos sociais minoritários], como também torná-las presentes" (Pogrebinschi, 2013, p. 174).

Essa estratégia pragmática permite a defesa do papel de cortes constitucionais como instâncias representativas mesmo com o reconhecimento de que falham os mecanismos de legitimação a elas associados. Aqui, a representação não eleitoral no Judiciário seria a solução institucional que, na prática, permitiria lidar melhor com um problema concreto, que é a ausência de brechas para a efetiva representação dos grupos sociais minoritários. A legitimação para o exercício de um papel representativo por parte de tribunais dar-se-ia justamente pela "falibilidade dos sistemas eleitorais e a dificuldade dos mecanismos de votação em tornar democráticos os seus resultados e as decisóes das instituiçóes políticas majoritárias" (Pogrebinschi, 2013, p. 179).

$\mathrm{Na}$ ausência de mecanismos explicativos, porém, tal vínculo parece dependente por completo da sensibilidade subjetiva e da boa vontade dos juízes. Há dois conjuntos de problemas que permanecem a descoberto. O primeiro é quanto à possibilidade de supervisão e controle das novas instâncias representativas. Afinal, uma das principais funçôes das instituiçôes eleitorais que estão sendo descartadas, mesmo que realizada de maneira insatisfatória, é garantir que os representantes não estejam demasiado afastados daqueles que deveriam representar, garantindo a vinculação entre o desenho institucional e o ideal normativo da soberania popular. Defender o deslocamento de "questóes de justificação, avaliação e legitimidade da democracia de um plano ex ante para um ex post" (Pogrebinschi, 2013, p. 181) é insuficiente e desemboca 
num consequencialismo que, na prática, abandona qualquer relaçấo com a ideia de democracia como governo do povo.

O segundo problema se vincula ao entendimento de quais são as minorias representadas pelo comportamento contramajoritário das cortes e quais estímulos explicam essa relação. Uma perspectiva materialista poderia indicar que, dada sua origem social, os juízes representam uma minoria bastante específica, as classes médias urbanas com formação universitária, seu perfil tendendo a coincidir com os estratos econômicos mais privilegiados conforme chegam às cortes superiores - adaptação, talvez, da famosa tese que via as forças armadas como a expressão política das camadas médias (Forjaz, 1977). Uma radicalização de tal posição a aproximaria da teoria do Estado capitalista de Poulantzas (2013 [1978]), segundo a qual os tribunais superiores podem incorporar a defesa dos interesses da burguesia, protegendo-os no momento em que as classes populares se tornam capazes de instrumentalizar a seu favor as instituiçóes eleitorais. Há aqui uma forma de representação de minorias, ancorada em origem social e interesses em comum, mas que dificilmente se credenciaria como democrática.

A autora nem cogita tal rumo. Suas minorias se parecem mais com grupos identitários, cuja cultura e modo de vida precisam ser resguardados de formas de violência institucionais e simbólicas perpetradas pela maioria. O resultado é uma versão repaginada da tese da tirania da maioria, adaptada aos novos tempos na medida em que concebe como objeto de proteção, não os mais ricos, mas a população LGBT, fiéis de cultos minoritários ou comunidades indígenas - e com um apelo à ideia de representação que é surpreendente à luz das versóes oitocentistas e novecentistas do argumento. Mas por que o Supremo encarnaria a defesa de tais minorias, sem que se explicite qualquer mecanismo que vincule seus integrantes a elas?

\section{A construção teórica da representação argumentativa}

Um passo adicional, do ponto de vista da sustentação teórica do papel do Judiciário, é a noção de representação argumentativa. A argumentação, isto é, a produção discursiva de razóes, aparece como o elemento diferenciado que a um só tempo confere maior legitimação ao tribunal e estabelece um critério de accountability. Aqui também está presente uma crítica de viés mais elitista à representação eleitoral. Desconfia-se do voto porque ele daria azo a impulsos majoritários, fundados em interesses egoístas de curto prazo, que potencialmente romperiam com direitos e garantias individuais. É esse o cerne do argumento em favor de tribunais que exercem o controle de constitucionalidade e funcionam como contrapeso ao parlamento. Aponta-se um tribunal não eleito como instituição capaz de exercer uma representação do povo que não está ancorada no voto, tido como veículo privilegiado para a expressão do auto-interesse, mas antes na razão e na força dos argumentos mobilizados. Essa visão, fortemente inspirada em uma concepção deliberativa de democracia, ${ }^{7}$ não está restrita aos bancos acadêmicos, alcançando até mesmo a retórica de autolegitimação de alguns juízes do Supremo Tribunal Federal.

Na formulação de Robert Alexy, a representação argumentativa é atrelada à afirmação da importância dos direitos constitucionais e de sua proteção por um corpo decisório formado por membros não eleitos. Segundo o autor, a única forma de conferir legitimidade democrática a tal corpo é associando o exercício da autoridade do tribunal a uma noção de representação - que não se ancora em qualquer forma de interação com os representados, mas sim na qualidade da produção argumentativa. Os juízes encarnam, assim, uma versão peculiar, em chave elitista, da "câmara de discursos" (um colegiado paralelo ao parlamento, em que se encontram representantes, não de populaçôes, mas dos diferentes discursos presentes na sociedade) proposta por Dryzek e Niemeyer (2008) para sanar o déficit deliberativo da democracia eleitoral.

O salto da autorização popular para a representação argumentativa é realizado de forma bastante singela. Segundo Alexy, uma democracia representativa não pode se fundamentar apenas em um modelo puramente decisionista, baseado em eleiçôes e decisóes pela regra da maioria. O ideal da democracia deliberativa demanda uma ampliação a partir da institucionalização do discurso como uma forma de tomada de decisão. Assim, a representação política exercida pelo parlamento deve ser, a um só 
tempo, "volitiva ou decisionista e argumentativa ou discursiva"8 (Alexy, 2014, p. 2016). Note-se, aqui, que Alexy percebe que a própria representação de instituições eleitorais também é, por assim dizer, argumentativa, visto que está fundada em seu potencial argumentativo.

Ocorre que, enquanto instituiçóes eleitorais oferecem esse mix de decisão/argumentação como fórmula representativa, uma corte constitucional seria

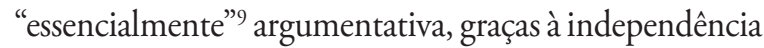
de que os juízes dessas cortes desfrutariam, já que não dependem do voto popular para a conservação de seus cargos. Segundo a tese, um tribunal "não tem o monopólio deste código, mas tem a virtude de operar exclusivamente com base nele. É monoglota" (Mendes, 2015 , p. 231). Nela há uma clara proximidade com percepçóes demofóbicas, segundo as quais o excesso de influência popular seria danoso para a racionalidade política, o que só faz enfatizar a oposição entre as duas lógicas opostas da legitimidade decisória, de que fala Rancière (2005, p. 86): a escolha da maioria e a capacidade de chegar às "boas soluçóes" para os problemas correntes. O próprio Alexy reconhece que para alguns críticos sua tese pode conferir um cheque em branco para tribunais, já que "a corte constitucional é livre para declarar todo e qualquer argumento como um argumento representando o povo" (Alexy, 2014, p. 208). Ele parece levar a sério a objeção; porém, registra que ela seria superável, concretamente, se a corte conseguisse demonstrar, em primeiro lugar, que a adjudicação constitucional não aceita qualquer coisa como argumento e, em segundo lugar, que seu processo de tomada de decisão está conectado "com o que o povo realmente pensa" (Alexy, 2014, p. 208).

Ou seja: a primeira resposta de Alexy segue no sentido de que tribunais que exercem a representação argumentativa devem estar realmente constrangidos pelo direito; a segunda, demanda algum grau de relação entre representante e representados. As duas respostas, contudo, são insatisfatórias e oferecem algum grau de contradição entre si. Como observa Arguelhes (2017, p. 83), "uma instituição não pode ser, ao mesmo tempo, desenhada de modo a se legitimar por ignorar o clamor popular e por atender a esse mesmo clamor popular".
No primeiro caso, demanda-se a existência de argumentos corretos, ou ao menos a pretensão de correção jurídica, como o próprio autor assinala expressamente. Não basta, diz ele, que os argumentos esgrimidos pela corte sejam populares; "ao menos no longo prazo, um número suficiente de pessoas deve aceitá-los com base em sua correção" (Alexy, 2005, p. 580). A menção ao longo prazo torna inviável qualquer tipo de controle das decisóes e faz uma aposta tácita na clarividência dos juízes. Ademais, para que se efetive a representação argumentativa, Alexy aponta para a necessidade não só de argumentos corretos, como também de pessoas racionais que estejam dispostas a aceitá-los como tais. Uma vez que tal ratificação não se confunde com a aprovação popular, fica claro que os indivíduos em posição de concedê-las formam um grupo com características distintivas. A representaçáo argumentativa confiada ao Judiciário, tal como aparece na formulação de Alexy, cumpre o papel elitista de reduzir o poder decisório do povo em regimes formalmente democráticos.

Nesse primeiro aspecto, a noção de representação argumentativa está mais claramente relacionada à teoria da decisão judicial que se arvora na racionalidade ${ }^{10}$ e na vinculação de juízes ao direito. Aproxima-se, em alguma medida, a teorias como a de Ronald Dworkin, para quem a revisão judicial é "a reserva de discurso principiológica da democracia” (Mendes, 2013a, p. 125). ${ }^{11} \mathrm{Na}$ condição de uma prática social argumentativa, a atividade de tribunais não se orienta pela disputa de interesses, como nas esferas representativas eleitorais, mas antes "depende da verdade de certas proposiçóes” (Dworkin, 1986, p. 13) com base no direito. ${ }^{12}$

No segundo caso, contudo, Alexy parece compreender que esse processo deliberativo seria suficiente para articular o tribunal ao que "o povo realmente pensa". Entretanto, o fato de deliberar racionalmente não aproxima automaticamente o tribunal de cidadáos racionais que convivem naquela sociedade, como parece supor o autor. Isso porque o funcionamento de cortes judiciais pode compreender procedimentos que Frederick Schauer chama de deliberativos porém não necessariamente públicos. Esse modelo de tomada de decisão reconhece a deliberação como melhor procedimento, "mas o público não é percebido como 
o melhor grupo para efetivamente deliberar" (Schauer, 1999, p. 21). Esse processo decisório corresponde à configuração institucional de cortes constitucionais e distingue-se sensivelmente da deliberaçâo pública, que de fato incorpora os cidadãos como participantes do processo deliberativo. A ideia de que ao deliberar racionalmente uma corte se conecta à sociedade demanda uma explicação mais sofisticada do que aquela fornecida por Alexy ${ }^{13}$.

Outra marca da tese diz respeito a um traço comum de teóricos da democracia deliberativa: uma crença exacerbada nos potenciais da argumentação, sem um reconhecimento de seus limites. Nutre-se um "apreço pela razão humana e a crença de que, dadas as circunstâncias adequadas, ela pode nos orientar em direção à superação dos nossos dilemas morais e à correta fundamentação das normas que regem nossa vida em comum" (Miguel, 2014, pp. 65-6). Para Alexy, a corte oferece um espaço privilegiado para o entendimento mútuo a partir do diálogo, por alijar completamente consideraçóes de ordem não argumentativa que são atraídas por procedimentos eleitorais. Assume-se, assim, que estariam neutralizadas diferenças de status, o que propiciaria um processo decisório mais adequado aos princípios inerentes à democracia. Isso tudo ignora o fato de que a deliberação possui limites, servindo muitas vezes para legitimar um discurso dominante, com resultado conservador - e também que os juízes, ainda que estejam num espaço próprio, nem por isso deixam de estar situados na sociedade, vendo o mundo de determinadas perspectivas, vinculados a grupos e interesses específicos. ${ }^{14}$

Em essência, a incorporação do conceito de representação política para se atribuir legitimidade democrática a cortes constitucionais em Alexy padece de problemas, notadamente (i) uma crença aparentemente ilimitada no potencial da deliberação desinteressada sobre direitos no seio de um tribunal, (ii) a ausência de quaisquer mecanismos tangíveis de verificação de uma suposta vinculação entre representante e representados e (iii) a ausência de formas de accountability por meio das quais os representados possam exercer controle sobre o tribunal que pretende representá-los argumentativamente. ${ }^{15}$ Se o mecanismo do voto é eliminado por conta do risco de contaminação indevida do fórum essencialmente deliberativo, nenhuma outra ferramenta é proposta em contrapartida, para que assim os representados possam aferir e eventualmente descartar argumentos que o tribunal tenha erigido como corretos.

De fato, Alexy não resolve o caráter paradoxal estabelecido pela convivência entre, de um lado, o discurso da representação política, que demanda uma vinculação efetiva entre representante e representados e exige a presença da multiplicidade de interesses existente no povo, e, de outro lado, o discurso dos direitos e do juízo isento, que pressupóe neutralidade de interesses da esfera deliberativa e se orienta pela noção de um processo decisório pretensamente imparcial que busca encontrar no direito a resposta correta. Por isso, sua perspectiva náo ajuda na tarefa de repensar as fronteiras da representação e as formas de seu exercício. A teoria soa como um recurso retórico para superar o déficit democrático dos tribunais sem modificar radicalmente as bases da atuação dessas instituições.

\section{O Supremo representante}

O que confere interesse à categoria da representação argumentativa não é apenas sua contribuição à discussão teórica, mas também sua influência sobre o debate institucional brasileiro, em particular no âmbito do Supremo Tribunal Federal. Sob a ótica dos juízes, a tese da representação argumentativa se oferece como um instrumento retórico interessante. Ela proporciona ao magistrado a oportunidade de, a um só tempo, dizer que sua decisão é constrangida apenas pelo direito, oferecendo uma resposta correta em seu aspecto jurídico e, no mesmo movimento, atribuir legitimidade popular ao julgado, estabelecendo-a como razão democrática do povo. Não gera surpresa, portanto, que o conceito tenha alcançado projeçáo em acórdãos do Supremo Tribunal Federal e escritos de alguns de seus ministros. ${ }^{16}$

Em diversas ocasiōes, ministros do Supremo se valeram da tese da representação argumentativa numa tentativa de legitimar o papel da corte. ${ }^{17}$ Ao menos dois ministros que assumem protagonismo dentro do tribunal, Gilmar Mendes e Luís Roberto Barroso, recorrem repetidamente a um suposto 
papel representativo do tribunal para reforçar sua legitimidade decisória em casos sensíveis sob o ponto de vista moral e político. Mais do que isso, ambos incorporam a tese a seus escritos acadêmicos, o que é particularmente relevante no contexto peculiar do ensino jurídico brasileiro, em que aqueles que vestem a toga transferem seu capital político-institucional aos bancos universitários e acabam por reforçar seu protagonismo intelectual no direito constitucional. Por isso, é importante compreendermos como essa tese é incorporada ao repertório discursivo de juízes como parte de uma retórica autolegitimadora. ${ }^{18}$

A definição de Alexy - "o parlamento representa o cidadão politicamente, o tribunal constitucional, argumentativamente" - foi evocada em uma primeira oportunidade pelo ministro Gilmar Mendes, então presidente do STF, na votação da Ação Direta de Inconstitucionalidade 3510, em que se discutiu a possibilidade de pesquisas científicas com células-tronco embrionárias. No julgamento, que foi finalizado em 29 de maio de 2008, Mendes proferiu o último voto do colegiado afirmando que a corte também deveria ser compreendida como a "casa do povo". Isso porque haveria, no tribunal, um ponto de encontro onde "diversos anseios sociais e o pluralismo político, ético e religioso encontram guarida nos debates procedimental e argumentativamente organizados em normas previamente estabelecidas" (STF, 2008).

Curioso notar como o juiz não ignorou o fato de que o próprio Congresso Nacional havia se debruçado sobre a matéria judicializada anteriormente, mas ressaltou que o debate instaurado no âmbito do Supremo teria sido renovado a partir da "nota distintiva da racionalidade argumentativa e procedimental própria de uma Jurisdição Constitucional" (STF, 2008). De fato, o artifício se mostra especialmente útil em casos com fundo moral, em que o colegiado tende a estar menos amarrado a critérios exclusivamente jurídicos e parece constrangido essencialmente por fatores extrajurídicos. Nessas ocasiōes, ministros podem encontrar refúgio no discurso da representação argumentativa para justificar uma decisão de teor mais subjetivo como supostamente originada de um fundamento democrático. ${ }^{19}$

De outro lado, a tese também oferece ao tribunal uma maneira de se apresentar ao público em geral como democrático, sem oferecer quaisquer ferramentas práticas que, de fato, efetivem essa aproximação com a soberania popular. Assim, para Mendes, o Supremo se constituiria em "um espaço democrático. Um espaço aberto à reflexão e à argumentação jurídica e moral, com ampla repercussão na coletividade e nas instituições democráticas" (STF, 2008).

Gilmar Mendes retomou a ideia de representação, com menção explícita a Robert Alexy, em entrevista concedida ao jornal Valor Econômico ainda em junho de 2008, logo após o simbólico julgamento sobre células-tronco. O ministro ocupava a presidência da Corte e, por isso, falava à mídia como voz da instituição. Mendes destacou a importância da participação da sociedade civil em processos do Supremo e declarou que o novo protagonismo do STF avançava sobre "vácuo" deixado pelo parlamento. Também apontou vantagem comparativa de processos decisórios judiciais, visto que "há uma cobrança de racionalidade dos parlamentares, mas ela não ocorre necessariamente". Enquanto os interesses prevaleceriam na arena legislativa, Mendes anunciava que "isso é o contrário do que acontece entre nós”, pois "as nossas decisóes só ganham peso se conseguem convencer" (Basile, 2008).

Esse tipo de uso retórico da tese foi retomado por Mendes em outro processo de temática moralmente saliente, a Arguição de Descumprimento de Preceito Fundamental 132, em que se debatia a constitucionalidade da união homoafetiva. Em seu voto o ministro evocou a ideia de representação argumentativa para defender que "não há exorbitância de nossa parte quando dizemos que a Corte está sendo chamada para decidir um caso que diz respeito aos direitos fundamentais e, no caso específico, de forma inequívoca, diz respeito a direitos de minoria” (STF, 2011). Ou seja, a tese não serviu de sustentação ao conteúdo da decisão propriamente dito, mas antes à autoafirmação institucional do tribunal como instância adequada do ponto de vista democrático para decidir questão de tamanha relevância. Fica evidente, assim, a utilidade da tese, não como critério decisório, mas antes como parte integrante do repertório discursivo de autolegitimação, que serve de forma mais poderosa para circunstâncias nas quais não há clareza quanto aos critérios jurídicos da decisão. ${ }^{20}$ 
Em um contexto bastante distinto, outro ministro do Supremo, Celso de Mello, valeu-se da ideia de representação argumentativa; no caso, não para justificar uma conexão com a sociedade, mas antes para se afastar de uma postura aproximada do "clamor público". Em um de seus votos na célebre Ação Penal 470, que julgou o escândalo do chamado "Mensaláo" (o esquema institucionalizado de corrupção para garantir apoio parlamentar ao presidente da República), Celso de Mello apoiou-se em citação de Alexy sobre o tema para destacar que o processo decisório do Supremo deve transcorrer em ambiente institucional que "valorize a racionalidade jurídica" (STF, 2013).

Alguns aspectos dessa manifestação merecem atenção. Em primeiro lugar, convém destacar que o julgamento do "Mensaláo" representou um dos momentos cruciais de virada no papel institucional do STF no sistema político brasileiro. A situação inédita, na qual a corte defrontava-se com a possibilidade de decretar a prisão de políticos do primeiro escalão no exercício do poder, dotava de especial relevância a questão da legitimidade do colegiado para proferir qualquer decisão. Assim, o recurso à legitimação democrática pela deliberação racional conferia aos ministros um subsídio argumentativo interessante para driblar eventuais imputaçōes de politização. Ao se declarar como representante argumentativo, Mello buscava menos uma conexão com seus representados e mais um artifício para reforçar sua racionalidade comparativamente superior a outros atores ou instituiçóes. Isso é evidenciado pelo trecho escolhido da obra de Alexy para transcrição em seu voto:

A única possibilidade de conciliar a jurisdição com a democracia consiste em compreendê-la também como representação do povo. Não se trata, obviamente, de um mandato outorgado por meio do sufrágio popular, mas de uma representação ideal que se dá no plano discursivo, é dizer, uma 'representação argumentativa'. Essa representação argumentativa é exercida não no campo das escolhas políticas - cujas deliberaçóes versam (predominantemente) sobre o que é bom, conveniente ou oportuno -, mas no campo da aplicação do direito, sob as regras do discurso racional por meio do qual se sustenta e se declara o que é correto, válido ou devido (Alexy, 2007, p. 163).

Além disso, as circunstâncias em que o voto foi proferido também foram singulares. Na condição de decano, Mello proferiu o voto decisivo que determinou o resultado do julgamento em 6 a 5, formando maioria em favor do cabimento dos embargos infringentes na Ação Penal 470. Na prática, isso representava a possibilidade de um recurso adicional aos réus do "Mensaláo". O uso do argumento da representação pela razão vinha para lidar, portanto, com uma série de manifestaçóes da imprensa e da sociedade civil nos dias anteriores, que expressavam posição oposta àquela defendida pelo ministro. ${ }^{21}$

Fica marcado, portanto, um notável contraste entre os usos da tese feitos pelos ministros Mendes e Mello. De um lado, o primeiro sustentou-se na ideia de representaçáo para aproximar o Supremo a uma "casa do povo", revestida dos necessários atributos democráticos para decidir matérias sensíveis do ponto de vista moral e político, mesmo quando os materiais legais em jogo eram limitados e fatores extrajurídicos detinham um papel preponderante sobre a decisão. De outro, o segundo apoiou-se na representação argumentativa para se afastar do "clamor público" e resgatar a vinculação estrita do tribunal com a correção do ponto de vista jurídico. Ou seja, a tese serviu de blindagem discursiva para decisão judicial politicamente saliente e controversa. Isso tudo explicita que a tese da representação argumentativa, além de sua fragilidade teórica, pode transmutar-se em instrumento retórico com maleabilidade suficiente para apoiar sentidos bastante diversos de posicionamentos judiciais.

Mais recentemente, o ministro Luís Roberto Barroso vem desenvolvendo em textos acadêmicos a tese da representação pelo STF. Barroso é um típico caso de transferência recíproca entre o capital acumulado na academia e na carreira jurídica. Professor titular de direito constitucional da Universidade Estadual do Rio de Janeiro, valeu-se de reconhecidas credenciais acadêmicas para alcançar o posto de ministro do STF e, nessa posição, reforça seu prestígio nos bancos universitários. Assume, assim, um duplo papel de juiz/decisor e comentarista/doutrinador, escrevendo 
no e sobre o Supremo em ambos os ambientes institucionais.

No que toca ao desenvolvimento teórico da noção de representação, Barroso segue integralmente a tese de Alexy. A função representativa do Supremo seria fundada em uma legitimidade discursiva, visto que suas decisões são precedidas de um processo deliberativo a partir do qual devem ser fornecidas razóes para fundamentar as escolhas definitivas. Ele replica a ideia de que a "democracia é feita de votos e argumentos" (Barroso, 2016, p. 81). Mas vai além ao aplicar a tese ao contexto brasileiro. Discutindo decisóes recentes do Supremo sobre questóes que envolviam grandes conflitos morais e políticos, Barroso estabelece a primazia de nosso Judiciário sobre os outros poderes no que diz respeito à capacidade de representar, afirmando que "juízes e cortes se tornaram mais representativos das aspiraçóes e demandas sociais que as instituiçôes políticas tradicionais" (Barroso, 2016, p. 78).

Ou seja, o ministro não ignora que a ideia de representação envolve uma necessária conexão entre representante e representados, mas defende que o Supremo nutre uma "intensa e contínua interação com a sociedade civil” (Barroso, 2016, p. 79). Seu ponto é tentar mostrar que o caráter representativo do Supremo se desdobra em duas características: (i) uma conexão entre corte e sociedade, que muitas vezes seria mais forte que a ligação entre a população e as instituiçóes nascidas do processo eleitoral, e (ii) um potencial de realizar decisóes a partir de um rigoroso processo deliberativo. ${ }^{22}$

Barroso, portanto, parece ir além de seu inspirador alemão ao defender o papel representativo do Supremo ${ }^{23}$. Como consequência, dedica-se mais atentamente à necessidade de vinculação do representante com seus representados, buscando, a todo tempo, defender o Supremo como uma instituição mais apta a exprimir o "sentimento" do povo brasileiro. Apesar de se deitar sobre fundamento um tanto místico para dar conta da capacidade de conexão do tribunal com a sociedade, o autor enumera algumas práticas institucionais que permitiriam esse resultado, como a realização de audiências públicas e a intervenção de amici curiae, instituto que permite a participação da sociedade em processos judiciais.

O que o ministro parece não levar em conta é a natureza do papel que se atribui a cidadãos no processo judicial, que é fator impeditivo para considerarmos a existência de processos participativos vigorosos dentro da corte, como fazem crer seus defensores. Em linhas gerais, o público não tem espaço para de fato participar dos processos deliberativos de tomada de decisão. O que ocorre é uma abertura momentânea para que se apresentem informaçóes, em uma etapa pré-decisional (Mendes, 2013b, p. 127), para apenas então os juízes recolherem esse material e exercerem uma deliberação que se deseja racional sobre os direitos em jogo. A tese da representação argumentativa ou mesmo da "representação meritocrática", aventada com mais cautela por Philip Pettit (2013), não dá o devido peso ao fato de que, ainda que as partes possam ser manifestar no tribunal (e aceitando sem contestação que os querelantes de fato encarnam o conjunto das posiçóes relevantes), há uma desigualdade de partida, já que só os juízes têm o poder de decidir. Mesmo que a interação entre Supremo e sociedade civil ocorra da forma como Barroso indica, ela é fluida, informal e sobretudo assimétrica, na medida em que não é concedida aos representados putativos nenhuma capacidade de sanção sobre os tomadores de decisão. ${ }^{24}$ Ou seja: o advogado, que é accountable diante de seus representados, não tem poder decisório. $\mathrm{O}$ juiz, que tem esse poder, não é accountable.

A apropriação do discurso da representação argumentativa por juízes do Supremo não supera suas fragilidades, e assim explicita seus paradoxos. A retórica da representação, em vez de apontar para a institucionalização de mecanismos de accountability efetivos, que possam colocar em funcionamento um controle democrático do Judiciário, tem ocasionado um efeito contrário. Ao se anunciar como representante argumentativo, o Supremo Tribunal Federal assume um papel ambíguo, ora propondo-se como o dono da razão, aquele que diz o que é certo sob o ponto de vista jurídico, a despeito do clamor popular, ora associando-se à vontade dos cidadáos, exprimindo o real sentimento do povo. O que ocorre, contudo, é que se estabelece um formato perverso pelo qual o tribunal se vale da ideia de representação para ampliar seu isolamento em um espaço olímpico de decisão, alimentando a natureza mítica de sua função, sem quaisquer controles por parte da sociedade.

Não se trata de concordar ou discordar das decisóes efetivamente adotadas pelo STF em casos 
que receberam atenção pública. A questão é perceber como a incorporação do discurso da representação argumentativa no universo mental de alguns ministros assume esse caráter ambíguo, ora postulando a maior conexão com o sentimento público e, portanto, abrindo espaço para uma fuga dos constrangimentos jurídicos, ora assumindo o caráter de uma associação mais estrita com um método decisório unicamente a partir de direitos. Mais do que afirmar evidência anedótica da influência de um argumento teórico questionável pelo STF, buscamos demonstrar como a tese da representaçáo foi incorporada ao repertório discursivo ao qual juízes podem recorrer para buscar legitimar sua própria autoridade. Com isso, em sentido contrário ao fundamento teórico da própria noção de representação democrática, o argumento serve para que o tribunal brasileiro se afaste cada vez mais de mecanismos efetivos de controle popular.

Assim, se a princípio o esforço teórico de elaboraçáo do conceito de representaçáo política teve como alicerce a ideia de tornar a adjudicação constitucional compatível com critérios de legitimidade democrática, seu efeito tem sido uma perpetuação do discurso esotérico que eleva a corte constitucional a uma posição de descoberta racional da verdade. Em que sentido, então, podemos dizer que nossos juízes constitucionais nos representam?

\section{Representaçáo popular ou elitismo?}

A reivindicação representativa do Supremo Tribunal Federal, que recorre à teoria de Alexy ou ao menos à imagem que ela projeta das funçóes do Judiciário, participa de um movimento bem mais amplo de disputa sobre o sentido da representação democrática. A disputa tem como pano de fundo a crise dos modelos eleitorais de delegação do poder, que se tornaram a base das democracias políticas liberais. Os eleitores não se sentem representados por aqueles que elegem para a tomada de decisóes. Assim, "é possível detectar uma crise do sentimento de estar representado, que compromete os laços que idealmente deveriam ligar os eleitores a parlamentares, candidatos, partidos e, de forma mais genérica, aos poderes constitucionais" (Miguel, 2014, p. 98).
Diante desse diagnóstico, abre-se caminho seja para buscar remédios para a crise, seja para argumentar que ela possui na verdade um caráter conceitual. $\mathrm{O}$ problema residiria no fato de que a ideia de representação está fossilizada; náo acompanhou o florescimento das novas formas representativas na política contemporânea que prescindem de eleiçóes. Assim haveria a emergência de atores da sociedade civil que desempenham a representaçáo sem o requisito explícito da autorizaçáo e sem uma estrutura de monopólio territorial, com uma "superposição simultânea de diversos tipos de representaçôes", como escreveu em outro contexto Leonardo Avritzer (2007, p. 444). Emergem daí duas perguntas. A primeira, mais geral, é se tais relaçôes são capazes de assumir simultaneamente as qualidades de representativas, democráticas e legitimas - afinal, reconhecer que alguém fala em nome de outros, isto é, age como representante, não implica que o faz com legitimidade ou de acordo com procedimentos democráticos (Miguel, 2017). A segunda pergunta, mais focada no caso sob análise, é se pode a representação argumentativa exercida por um tribunal ser um desses canais com o potencial de reinstalar o sentimento de estar representado.

Há problemas na incorporação dessa ideia pela retórica de juízes do STF, tanto devido a incongruências e paradoxos teóricos, como em virtude de aspectos relativos ao funcionamento prático da corte. Em vez de sustentar um ideal de representação efetivamente democrática, alargando e expandindo os sentidos do conceito para além das eleiçóes e conferindo maior proximidade com os representados, a construção do discurso do Supremo como instância representativa parece estar mais associada a uma radicalizaçáo do princípio da distinção analisado por Manin (1997, p. 94), no qual a cesura de background social e de competências entre representante e representado é maximizada. Aqui, a representação assume de forma contundente o caráter de seleçáo dos melhores para realizar a democracia, em um formato que, se não depende de um grau de participação mínima da população por intermédio do voto, tampouco avança para formas mais sofisticadas e constantes de aproximação entre representantes e representados.

O caráter elitista da justificaçáo do papel de tribunais em democracias é uma marca reiterada em trabalhos 
de teóricos do direito. Richard Posner, por exemplo, é inequívoco em sua defesa de uma adjudicação pragmática, segundo a qual juízes deveriam decidir com o olhar para o futuro, tendo em vista alcançar os "melhores resultados". Ao enfrentar objeçôes democráticas ao seu modelo de tomada de decisão judicial para o contexto estadunidense, ele afirma que esses temores são exagerados, já que "juízes das cortes superiores norte-americanas são geralmente selecionados da parte superior da distribuição populacional em termos de idade, educação, inteligência, desinteresse e sobriedade" (Posner, 1996, p. 11).

No caso dos ideólogos da representação argumentativa, esse ingrediente elitista não é assumido de forma tâo clara como em Posner, mas está presente de forma implícita. A representação argumentativa, especialmente na forma pela qual tem sido incorporada por juízes do Supremo Tribunal Federal, mais se aproxima de um paternalismo epistêmico (Goldman, 1991), que se oferece como imposição de juízos políticos e morais, servindo de substituto racionalmente superior a um processo pelo qual se abririam espaços de participação em que o próprio povo exerce sua autonomia democrática. ${ }^{25}$

Em vez de exprimir uma forma de representação expandida para além das eleiçóes, a esperança em uma representação argumentativa por uma corte constitucional seria mais bem enquadrada como um retrocesso a uma representação aquém das eleiçóes. Enquanto o esforço de teóricos preocupados em desacoplar representação e voto opera-se com o fomento a mecanismos participativos que envolvam mais diretamente a sociedade, o sentido da representação argumentativa parece ser o contrário. Em um contexto no qual a representação é exercida primordialmente por um tribunal, a sociedade assume o papel de audiência e, quando muito, fornece elementos informacionais para que juízes, dotados de uma capacidade cognitiva superior, possam extrair a razão que mais coaduna com o direito e com o sentimento real, mesmo que não consciente, da população.

Outro problema é próprio à natureza da função judicial e também gera enigmas não resolvidos pela apropriação do discurso da representação por tribunais. As disputas em instâncias representativas são usualmente enquadradas como conflitos de interesses que se manifestam na esfera pública. Por meio delas, os diversos interesses se fazem presentes, são expressos dentro da arena política e disputam espaço. Mas a metamorfose de um discurso de interesses em um discurso de proteção de direitos já assignados busca arrefecer o caráter conflituoso e atribuir um sentido técnico ao processo decisório. Com efeito, o resultado de uma disputa em instâncias eleitorais faz vencedores e perdedores momentâneos, enquanto o resultado de uma disputa em instâncias judiciais distingue o legal do ilegal, o constitucional do inconstitucional, o correto do incorreto. Nessa medida, enquanto derrotados na política perseveram em sua batalha com a perspectiva de um dia se tornarem vencedores, os errados no direito são estigmatizados; sua posição não é legítima sequer para continuar marcando presença no campo político, devendo abrir espaço para que o outro prevaleça de forma definitiva. ${ }^{26}$

Uma vez que a relação entre os juízes e aqueles que eles dizem representar é definida pelo diferencial de competência entre uns e outros, do qual deriva a impossibilidade de supervisão da ação por parte dos que seriam representados, não há como afiançar o caráter de suas decisóes - de defesa dos direitos de minorias ameaçadas, como deseja Pogrebinschi; de expressão de uma vontade popular difusa e latente, como propóe Barroso; de encarnação da racionalidade, segundo o olhar de Mello; ou mesmo, conforme vozes mais críticas, de proteção de interesses já privilegiados. No fim, tudo parece em boa medida depender das virtudes pessoais dos magistrados (que a Constituição brasileira, de forma sintética, indica como sendo "reputação ilibada" e "notório saber jurídico"). Mesmo que se deixe em suspenso o possível questionamento sobre a efetividade de tal abordagem, que se prende à ideia de que seria possível superar os conflitos desde que se empreguem boas qualidades na busca do bem comum, seria necessário indagar quais mecanismos garantem que os ministros do STF de fato preenchem o perfil que deles se espera. Indagação que pode ser incômoda no caso brasileiro, em que o crivo ao qual se submetem os indicados à corte suprema é notoriamente lasso e as polêmicas sobre o caráter e a competência dos candidatos ao cargo não são infrequentes. ${ }^{27}$ 
Os mecanismos de supervisão e controle não estão apenas ausentes; sua inexistência é formulada como virtude e condição necessária para que as cortes exerçam a contento suas funçóes - inclusive as que se querem representativas. Assim, a representação operada por tribunais, em vez de servir como espaço para proteger interesses minoritários, como deseja Pogrebinschi, pode servir de forma ainda mais radical como um espaço conservador para a homogeneização do discurso público e a manutenção do status quo, estigmatizando como equivocadas e inaceitáveis as posiçóes perdedoras. Dada a conformação institucional do Supremo, em que os juízes são selecionados a partir de uma série de filtros que lhes conferem uma composição social homogênea e alinhada a grupos políticos dominantes, dos quais depende o acesso ao cargo, não parece restar tanto espaço quanto se imagina para uma representação pró-minoritária radical, especialmente em um contexto no qual não se fazem presentes quaisquer ferramentas para que aqueles supostamente representados tomem parte como agentes do processo decisório.

\section{Conclusão}

No livro que assentou as bases da discussão sobre representação política dos últimos cinquenta anos, Hanna Pitkin destaca o caráter multifacetado do conceito, que é contaminado pelos diferentes usos do verbo "representar" em múltiplos contextos sociais e não se resume às instituiçóes associadas às democracias representativas ocidentais. Se "representar" é falar em nome de outros, então todo exercício do poder político é, em alguma medida, representativo. Mas a autora observa que nossa noção de governo representativo possui um conteúdo normativo distinto. Não basta que o governo seja capaz de exercer efetivo controle sobre seus sujeitos, mas, ao contrário, "que os sujeitos possuam controle sobre o que ele faz" (Pitkin, 1967, p. 232). Isto é, “a questão da vinculação dos representantes aos representados possui uma centralidade absoluta na discussão sobre qualquer ordem democrática” (Miguel, 2014, p. 95).

No Brasil, a tese da representação argumentativa foi incorporada por alguns juízes constitucionais como tentativa de legitimação, em casos concretos, de decisóes sobre conflitos que envolveram disputas de interesses políticos e morais centrais em nossa sociedade. De forma mais geral, também operou como justificativa adicional para a autoridade decisória do tribunal. No papel de representante pelo argumento, o Supremo ostentaria o título de dono da razão, capaz de expressar a vontade geral. Isso tudo colocaria sobre a corte um ônus considerável do qual ela não é capaz de se desvencilhar. Essa forma de justificaçáo pela representação política para dar conta de um papel transformador que ultrapassa os limites da tradicional passividade/reatividade judiciária, desenvolve-se a partir de um paradoxo entre defesa de direitos desinteressados e relação com os interesses populares mais latentes. Argumentamos que o aprofundamento dessa tensão tende a gerar resultados pouco promissores sob o ponto de vista democrático.

À medida que juízes do Supremo encontram artifícios retóricos para escapar de constrangimentos decisórios, arvorando-se em um ideal mais abstrato de representação pela razão, podemos observar ao menos duas consequências perversas à luz de ideais democráticos: (i) em primeiro lugar, opera-se o aprofundamento de um fundamento místico e esotérico de legitimidade do tribunal, distanciando cada vez mais o colegiado de seus pretensos representados e desprovendo o povo de mecanismos de controle minimamente eficazes; (ii) em segundo lugar, a crença unívoca e radical na capacidade deliberativa do tribunal como forma de encerrar o conflito inerente à democracia pode aprofundar a passividade da sociedade e forçar uma tendência de manutenção do status quo.

Trata-se de um movimento teórico que segue o caminho trilhado por parte da vertente deliberacionista, que abandonou o ideal inicial de formação de preferências na esfera pública ampla e propôs em seu lugar colegiados decisórios elitizados onde cidadãos comuns são relegados à posição de meros espectadores ou, quando muito, de fornecedores de informação. Assim perde-se, de forma inevitável, o lastro democrático da representação política, que deveria ser mais atenta à autonomia e à participação efetiva dos representados na definição de seus próprios rumos. Em vez de representados politicamente engajados, exercendo proximamente o controle de seus representantes, cidadáos protegidos pela 
representação argumentativa não seriam muito mais do que "otimistas espectadores de um governo dos juízes”, nas palavras de Pogrebinschi (2013, p. 166). É difícil conceber a representação exercida pelo Supremo como democrática quando não se percebe qualquer grau de responsividade às preferências dos cidadáos, nem tampouco mecanismos de controle por meio dos quais a sociedade possa efetivamente distinguir um tribunal representativo de um tribunal não representativo e, eventualmente, aplicar sançôes (Manin, Przeworski e Stokes, 1999, pp. 9-10).

Por tudo isso, a chave teórica da representaçáo não funciona adequadamente como categoria para pensarmos a prática institucional do Supremo Tribunal Federal. Se assumirmos, como Manin, que o governo representativo contém uma dualidade entre elementos democráticos e antidemocráticos, a crença na representação argumentativa pelo Supremo pode acabar nos distanciando ainda mais do polo democrático, e não o contrário, como pretendem seus idealizadores. Mesmo em casos em que o ativismo da corte adota caráter progressista, rompendo com a inércia do legislativo para estender garantias a grupos em posição subalterna, como mulheres ou LGBT, trata-se de uma intervenção de caráter mais liberal (de proteção a direitos) do que democrático (de obediência à soberania popular).

No fim das contas, não é possível escapar do enfrentamento direto da questão que se propóe neste artigo desde o início: qual o papel de instituiçôes que não respondem ao povo num ordenamento institucional que se deseja democrático? A resposta clássica, do guardião da norma legal para além das paixões do momento, parece não satisfazer mais nem às próprias cortes. Há um espectro de respostas possíveis. A Constituição boliviana aprovada em 2009, como parte de um autodeclarado projeto de aprofundamento democrático, determinou a eleição popular dos magistrados. Já para Pierre Rosanvallon, no campo oposto, a legitimidade democrática não se esgota na autorização popular, mas passa por mecanismos alternativos como proximidade, imparcialidade e reflexividade - que, sobretudo os dois últimos, contemplariam as cortes judiciais (Rosanvallon, 2008). No entanto, sua reflexão se dá no bojo da compreensão de que vivemos uma era de "contrademocracia”, em que o poder do povo serve mais para impedir abusos dos governantes do que para determinar o conteúdo das políticas (Rosanvallon, 2006), baseada por sua vez numa leitura sociológica contestável, de que os sistemas de diferenciação estrutural se tornaram menos marcantes, tornando a sociedade virtualmente irrepresentável e, assim, invalidando o próprio ideal de democracia representativa tal como em geral compreendido (Rosanvallon, 1998, 2011).

Ao ser alçado como "representante do povo", o Supremo adquire autoridade decisória pela razão democrática sem assumir os ônus institucionais que esse passo demanda. ${ }^{28}$ Em seu livro já clássico, Manin atribui ao governo representativo um caráter dissociado da noção de democracia, afirmando que ele nada mais é, desde sua origem histórica, do que "uma governança de elites que se distinguem da maior parte dos cidadãos por sua posição social, modo de vida e educação" (Manin, 1997, p. 232). A promessa de um STF como instância representativa não oferece um cenário muito mais virtuoso que esse.

\section{Notas}

1 O termo, que ganhou notoriedade na obra coletiva editada por Tate e Vallinder (1995), serviu de ponto de convergência de boa parte dos estudos sobre o Judiciário no Brasil, tendo como cerne a ideia de "abarcar as causas e consequências da expansão do poder Judiciário nos processos políticos das democracias contemporâneas”, bem como o "[...] poder de intervenção [...] fortemente relacionado com a amplitude do desenho constitucional, pois quanto maior for o nível de regulamentação da sociedade, maiores serão as chances de uma intervenção judicial" (Peres e Carvalho, 2012, p. 98). Registre-se também a proliferação de críticas ao conceito de judicializaçáo e sua incorporaçáo pela academia brasileira, especialmente no que diz respeito à atribuiçáo de um sentido normativo ao termo (Maciel e Koerner, 2002; Nobre e Rodriguez, 2011; Koerner, Inatomi e Baratto, 2011).

2 A fluidez conceitual do termo "ativismo judicial" contrapóe uma dificuldade de instrumentalização que reduz sua utilidade analítica com a facilidade de apropriação que a tornou "moeda corrente" no debate público, em particular na mídia. Como argumentam Arguelhes, Oliveira e Ribeiro (2012), a falta de consistência da expressão não pode redundar em sua exclusão pura e simples dos 
estudos acadêmicos, mas certamente demanda cuidados para que não se torne mero elemento retórico.

3 A teoria da representaçáo política nunca circunscreveu-se à representaçáo eleitoral (basta ver a obra fundadora de Pitkin, 1967). A difusão do modelo democrático representativo, no entanto, fez com que a representação eleitoral fosse dotada de uma legitimidade considerada inalcançável para outros vínculos representativos. O que parte da literatura recente tem feito é desafiar esse veredito.

4 Não obstante a incorporação do viés de gênero na própria norma padrão da língua portuguesa, a utilização do masculino na pergunta do texto também busca interpelar uma característica perene da composiçấo do Supremo Tribunal Federal, com impactos relevantes quando indagamos o quáo representativa a Corte pode ser.

5 Não se está dizendo que não possam existir tentativas de compatibilizar presença política e representação autoinstituída, mas sim que o mecanismo de legitimação da relação de representação é diverso.

6 A ruptura institucional de 2016, com a deposição da presidente Dilma Rousseff e o propósito de destruição do espírito da carta constitucional por aqueles que assim chegaram ao poder, projeta uma sombra sobre a continuidade das inovaçóes democratizantes no Brasil. No mesmo momento, o Judiciário reforçou seu protagonismo, ao cumprir duplo papel como fomentador e avalista da quebra das regras do jogo político vigente, o que reforçou a necessidade de uma justificativa discursiva para sua ação. No entanto, essa conjuntura, que ainda está em aberto, foge do escopo do presente artigo.

7 Outros pensadores de matriz deliberacionista conferem a tribunais judiciários o status de local privilegiado de deliberação, ainda que não avancem sobre o argumento de representação democrática. John Rawls, por exemplo, trata a Suprema Corte dos EUA como "exemplar da razão pública” (Rawls, 2005 [1993], p. 235).

8 As citaçóes de trabalhos em língua estrangeira neste artigo foram traduzidas pelos autores.

9 Em seu texto original, Alexy defende tribunais como instâncias "puramente" argumentativas, porém retrocede em resposta à crítica de Mattias Kumm (2012), reconhecendo como mais adequado o termo "essencialmente" argumentativo. Ele mantém contudo no cerne de seu argumento o reconhecimento de que juízes não possuem nenhum mecanismo de "legitimação democrática direta” e que a população não possui meios institucionais de controlar cortes (Alexy, 2012, p. 338).

10 Os critérios de racionalidade desenvolvidos por teóricos do direito, como Alexy, possuem maior rigor do que a mera ideia de constrangimento pode transmitir.
Assim, por exemplo, o autor alemão estabelece um instrumental metodológico estrito para o exercício da decisão judicial, sendo até mesmo acusado por alguns de hiper-racionalismo (ver Leal, 2017). Para o propósito do argumento teórico aqui desenvolvido, contudo, as ideias de racionalidade jurídica e constrangimento pelo direito são tratadas como equivalentes.

11 As teorias do direito de Robert Alexy e Ronald Dworkin apresentam inúmeros pontos de descolamento. Nesse quesito, porém, a aproximaçáo entre ambos joga luz sobre um aspecto nitidamente contraditório da apropriação do conceito de representação política por parte de Alexy, como se verá mais adiante.

12 Na base da teoria de Dworkin está uma fronteira clara entre argumentos de política e argumentos de princípios, que serviria para delimitar a divisão de atribuiçóes entre tribunais e parlamentos (Dworkin, 1985, pp. 33-71; Kyritsis, 2017, pp. 66-70). A corte seria o fórum do princípio, onde as decisóes são baseadas nos direitos individuais de cada cidadáo, e náo em políticas voltadas para o bem coletivo e o bem-estar social.

13 Um possível subtexto kantiano, presente em muitas das formulaçôes deliberacionistas, diria que os representantes argumentativos alcançam as soluçóes que o povo alcançaria caso fosse capaz de aplicar a razáo. Mas o ideal democrático exige a participaçáo efetiva, não presumida, do povo no processo decisório e espaços de educação política que permitam a todos fazer escolhas mais esclarecidas.

14 A folclorizaçáo da noção de "lugar de fala" nos embates discursivos atuais não deve obscurecer que toda fala é, de fato, socialmente situada e que, por mais bem-intencionada que seja, qualquer fala em lugar de outro pode contribuir para o silenciamento deste outro (cf. Alcoff, 1991; Young, 2000).

15 Na literatura da Ciência Política, a accountability tende a ser associada à obrigação de prestar contas (o agente) e à capacidade de imposição de sançôes (o diretor). Tentativas de expansão do conceito para relaçóes menos formais (Peruzzotti e Smulovitz, 2001; Waldron, 2016, cap. 8) são criticáveis por sua indeterminação, tornando a accountability co-extensiva a qualquer tipo de escrutínio público (Miguel, 2014). No caso do juiz da corte suprema, apresentá-lo como accountable e, ao mesmo tempo, manter a legitimidade advinda de sua independência leva a uma contradição lógica: é como querer comer o bolo e também mantê-lo. De resto, a possibilidade de superaçáo de decisóes do Supremo, por exemplo pela aprovação de nova legislação, não implica accountability - que é um atributo do tomador de decisão, não da decisão tomada. 
16 A seleção dos casos apresentados neste artigo foi realizada a partir de pesquisa bibliográfica focada em textos produzidos por ministros da corte e de pesquisa textual em base de dados disponibilizada pelo sítio eletrônico do STF que abrange a totalidade de seus julgamentos. Os acórdãos do Supremo foram extraídos de pesquisa jurisprudencial sobre base de decisôes disponibilizadas até a data de submissão do manuscrito deste artigo, filtrados a partir de resultados obtidos por busca dos termos-chave "representação argumentativa", "representatividade", "representação política", "representação democrática" e "representativa". O número baixo de referências explícitas ao termo, indicadas ao longo deste artigo, contrasta com a importância qualitativa das decisóes em que elas ocorreram, por razóes que buscamos elaborar mais adiante. Com relação aos escritos de ministros, foi realizada pesquisa de textos acadêmicos a partir das plataformas Lattes e Google Scholar, além de busca por entrevistas desses mesmos atores a veículos de imprensa. Em essência, nosso propósito é apontar os equívocos e riscos de uma determinada teoria. Assim, o esforço empírico, ao lançarmos máo de dados sobre decisóes e escritos de ministros, possui o limitado objetivo de demonstrar que essa teoria vem ganhando espaço relevante no contexto do STF e apontar a forma pela qual esse movimento acontece. Não buscamos estabelecer, a partir de tais dados, uma descrição de comportamento regular do STF, mas antes descrever a forma de incorporação de uma determinada teoria no pensamento jurídico e em decisóes de alguns juízes constitucionais.

17 A investigação recai sobre a retórica de ministros, individualmente, também por uma característica institucional do Supremo. Estudos recentes explicitam a necessidade de atentarmos à dimensão individual, visto que ministros detêm um conjunto ampliado de ferramentas decisórias à disposição sem necessidade de mediação pelo colegiado (Arguelhes e Ribeiro, 2018b; Arguelhes e Hartmann, 2017). Arguelhes e Ribeiro caracterizam essa alocação individualizada e descentralizada de poderes na corte como "ministrocracia" (Arguelhes e Ribeiro, 2018a). Os discursos aqui analisados constituem uma seleção não aleatória, sem pretensão de representatividade amostral, que se presta ao objetivo de apontar a presença desta démarche argumentativa entre os integrantes da corte suprema brasileira.

18 A ausência de pretensão de representatividade amostral dos casos analisados não minimiza o impacto do debate teórico sobre representação argumentativa na prática do STF. Compreender em que tipo de caso e diante de quais circunstâncias decisórias ministros lançam mão da tese ajuda-nos a perceber como e por quais razóes esse argumento é incorporado ao repertório discursivo de juízes.
19 Após essa primeira citação, Mendes faz uso recorrente do mesmo trecho de Alexy (e.g. julgamentos da ADI 4277 e da ADPF 132).

20 Concretiza-se nessa medida o risco de que a tese da representação seja mobilizada para "atuar como um avatar democrático que mascara o decisionismo nos julgamentos de casos difíceis" (Pereira, 2017, p. 373).

21 O contexto pode ser apreendido em notícia disponível em https://www.conjur.com.br/2013-set-18/leia-votocelso-mello-conceder-embargos-infringentes

22 Ainda que o debate teórico deste artigo se concentre sobre o primeiro ponto, deve-se apontar que a segunda característica apontada por Barroso é igualmente problemática. A literatura apresenta uma série de estudos que demonstram a baixa qualidade do processo deliberativo do STF (Silva, 2013), incluindo uma tendência decisória que se afasta do colegiado e confere cada vez mais espaço para decisóes individuais de juízes, de modo que o debate sobre deliberação coletiva perderia seu próprio sentido de ser (Arguelhes e Ribeiro, 2015, 2018a, 2018b). De outro lado, se voltarmos a atençáo ao plano do dever ser, não há nada que garanta que o processo deliberativo de cortes seja a priori mais virtuoso do que aquele a se desenvolver no parlamento ou em outros espaços que possibilitem maior participação popular na tomada de decisão.

23 Mais recentemente, respondendo a críticos, Barroso recua ao afirmar que o papel representativo seria exercido de forma "eventual" e "subsidiária". Nessa versão repaginada, a corte deveria ser representativa apenas quando o Legislativo, "órgão de representação popular por excelência”, falhar gravemente, sendo omisso no atendimento das demandas populares (Barroso, 2017, pp. 569-70). Aqui, o ministro afasta-se do argumento mais abrangente de Alexy, porém não apresenta critério convincente para delimitar as fronteiras desse dito papel supletivo da representação.

24 Esse mesmo equívoco consta de trabalhos recentes de acadêmicos da área jurídica que também buscam exprimir um caráter representativo a esses novos institutos de participaçấo da sociedade civil na jurisdição constitucional (ver Sombra, 2017).

25 Essa crença paternalista parece constituir marca persistente no sistema de justiça brasileiro. Em survey conduzido com membros do Ministério Público ao final dos anos 1990, Arantes atestou que $84 \%$ dos entrevistados consideravam a sociedade civil brasileira frágil e "hipossuficiente", incapaz de defender seus próprios direitos, tornando necessária uma atuação afirmativa das "instituiçôes de justiça" para "protegê-los" (Arantes, 2002, p. 128). O autor também apontava que esse voluntarismo se contrapunha a uma percepção de 
falência das instituiçôes políticas tradicionais. Assim, a ideia de cortes como representantes democráticas pode ser apenas uma nova forma de articulação teórica de um elitismo arraigado no pensamento daqueles que ocupam as carreiras jurídicas de alto escalăo.

26 É bem verdade que a politização mais ostensiva da ação do Judiciário compromete tal distinção. Embora o velho dito "decisão judicial não se discute, se cumpre" continue a ser evocado, os perdedores podem, com mais verossimilhança, impugnar o caráter realmente judicial do veredito, acusando-o de ser político, logo, sujeito à contestação.

27 Muito da literatura sobre o processo de seleçấo de integrantes do STF se dedica a demonstrar que os ministros náo se alinham necessariamente aos interesses do grupo político responsável por sua nomeação (Arguelhes e Ribeiro, 2010; Jaloretto e Mueller, 2011) - o que sinalizaria a conclusão de que o método de indicação e aprovação cumpre seus objetivos. Nosso ponto, no entanto, é outro. Mesmo com o acirramento da disputa política no Brasil, a aprovação dos indicados pela Presidência da República é quase automática, com sabatinas no Senado muito pouco exigentes (Paes, 2011) e votação favorável sempre amplamente majoritária. Mesmo diante do argumento de que a participaçáo de outro poder no processo de indicação pode gerar uma antecipação estratégica da Presidência da República, com uma guinada ao centro do espectro ideológico (e.g. Lemos e Llanos, 2013), o fato é que o escrutínio público nessa etapa de confirmação é quase inexistente. Polêmicas públicas sobre a adequaçáo dos candidatos, como José Dias Toffoli, em 2009 (pela baixa titulaçăo, inexperiência e condenaçóes em processos), ou Alexandre de Moraes, em 2017 (acusado de plágio em trabalhos acadêmicos), pouco reverberaram na decisão.

28 Ao contrário de Pereira (2017), não buscamos atribuir um sentido mais apropriado de representaçáo pelo Judiciário como forma de atrair novos ônus e limites ao STF, por compreendermos que se cuida de critério equivocado para aferir a funcionalidade democrática de um tribunal e que, por isso, deve ser descartado. O caminho mais promissor para se pensar o papel do Judiciário em uma democracia segue vinculado à tarefa de proteção de direitos a partir de sua peculiar capacidade institucional e das diretrizes conferidas pelo código jurídico-constitucional.

\section{BIBLIOGRAFIA}

ALCOFF, Linda. (1991), “The problem of speaking for others". Cultural Critique, no 20, pp. 5-32.
ALEXY, Robert. (2005), "Balancing, constitutional review, and representation". International Journal of Constitutional Law - ICON, vol. 3, no 4, pp. 572-81.

ALEXY, Robert. (2007), Constitucionalismo discursivo. Porto Alegre: Livraria do Advogado.

ALEXY, Robert. (2012), "Comments and responses", em Matthias Klatt (ed.), Institutionalized reason: the jurisprudence of Robert Alexy. Oxford: Oxford University Press.

ALEXY, Robert. (2014), "Constitutional rights, democracy, and representation". Ricerche Giuridiche, vol. 3, no 2, pp. 197-209.

ALMEIDA, Debora. (2015), Representação além das eleiçôes: repensando as fronteiras entre Estado e sociedade. Belo Horizonte: Paco.

ARANTES, Rogério Bastos. (1997), Judiciário e política no Brasil. São Paulo: Idesp/Sumaré.

ARANTES, Rogério Bastos. (2002), Ministério Público e politica no Brasil. São Paulo: Idesp/Sumaré.

ARGUELHES, Diego Werneck. (2017), "O Supremo que não erra”, em Oscar Vilhena Vieira e Rubens Glezer (orgs.), A razão e o voto: diálogos constitucionais com Luís Roberto Barroso. Rio de Janeiro: Editora FGV, pp. 81-107.

ARGUELHES, Diego Werneck e Ivar HARTMANN. (2017), "Timing control without docket control: how individual justices shape the Brazilian Supreme Court's agenda”. Journal of Law and Courts, vol. 5, no 1, pp. 105-140.

ARGUELHES, Diego Werneck, Fabiana Luci de OLIVEIRA e Leandro Molhano RIBEIRO. (2012), "Ativismo judicial e seus usos na mídia brasileira". Direito, Estado e Sociedade, no 40, pp. 34-64.

ARGUELHES, Diego Werneck e Leandro Molhano RIBEIRO. (2010), "Indicações presidenciais para o Supremo Tribunal Federal e seus fins políticos: uma resposta a Mariana Prado e Cláudia Türner”. Revista de Direito Administrativo, no 255, pp. 115-43.

ARGUELHES, Diego Werneck e Leandro Molhano RIBEIRO. (2015), "O Supremo individual: mecanismos de atuação direta dos Ministros sobre 
o processo político". Direito, Estado e Sociedade, no 46, pp. 121-155.

ARGUELHES, Diego Werneck e Leandro Molhano RIBEIRO. (2018a), "Ministrocracia: o Supremo Tribunal individual e o processo democrático brasileiro". Novos Estudos CEBRAP, vol. 37, nº 1, pp. 13-32.

ARGUELHES, Diego Werneck e Leandro Molhano RIBEIRO. (2018b), “'The Court, it is I'? Individual judicial powers in the Brazilian Supreme Court and their implications for constitutional theory". Global Constitutionalism, vol. 7, n 2, pp. 236-262.

AVRITZER, Leonardo. (2007), "Sociedade civil, instituiçôes participativas e representação: da autorização à legitimidade da ação”. Dados, vol. 50, no 3, pp. 443-64.

BARROSO, Luís Roberto. (2016), "Reason without vote: the representative and majoritarian function of constitutional courts", em Tomás Bustamante e Bernardo Gonçalves Fernandes (eds.), Democratizing constitutional law: perspectives on legal theory and the legitimacy of constitutionalism. Dordrecht: Springer Netherlands.

BARROSO, Luís Roberto. (2017), “Contramajoritário, representativo e iluminista: o Supremo, seus papéis e seus críticos”, em Oscar Vilhena Vieira e Rubens Glezer (orgs.), A razão e o voto: diálogos constitucionais com Luís Roberto Barroso. Rio de Janeiro: Editora FGV.

BASILE, Juliano. (2008), "Para o presidente do STF, tribunal supre deficiências do Legislativo". Valor Econômico, 9 jun. (caderno Política).

BELL, Daniel A. (1999), "Democratic deliberation: the problem of implementation", em Stephen Macedo (ed.), Deliberative politics: essays on Democracy and disagreement. Oxford: Oxford University Press.

CASTRO, Marcus Faro de. (1997), "O Supremo Tribunal Federal e a judicialização da política”. Revista Brasileira de Ciências Sociais, no 34, pp. 147-56.

DWORKIN, Ronald. (1985), A matter of principle. Oxford: Oxford University Press.

DWORKIN, Ronald. (1986), Law's empire. Oxford: Hart Publishing.
DRYZEK J John S. \& Simon NIEMEYER. (2008), "Discursive representation". American Political Science Review, vol. 102, no 4, pp. 481-93.

FALCÃO, Joaquim; OLIVEIRA, Fabiana Luci de. (2013), "O STF e a agenda pública nacional: de outro desconhecido a supremo protagonista?" Lua Nova, no 88, pp. 429-469.

FORJAZ, Maria Cecília Spina. (1977), Tenentismo e política: tenentismo e camadas médias urbanas na crise da Primeira República. Rio de Janeiro: Paz e Terra.

GOLDMAN, Alvin. (1991), "Epistemic paternalism: communication control in law and society". The Journal of Philosophy, vol. 88, no 3, pp. 113-31.

GURZA LAVALLE, Adrian, Peter P. HOUTZAGER e Graziella CASTELLO. (2006), "Representação política e organizaçóes civis: novas instâncias de mediação e os desafios da legitimidade". Revista Brasileira de Ciências Sociais, no 60, pp. 43-66.

HAMILTON, Alexander, James MADISON \& John JAY. (1990 [1788]), The Federalist. Chicago: Encyclopædia Britannica.

JALORETTO, Maria Fernanda e Bernardo MUELLER (2011), "O procedimento de escolha dos ministros do Supremo Tribunal Federal: uma análise empírica”. Economic Analysis of Law Review, vol. 2, no 1 , pp. 170-87.

KYRITSIS, Dimitrios. (2017), Where our protection lies: separation of powers and constitutional review. Oxford: Oxford University Press.

KOERNER, Andrei, Celly Cook INATOMI e Márcia BARATTO. (2011), "Sobre o judiciário e a judicializaçáo”. Nuevos Paradigmas de las Ciências Sociales Latinoamericanas, vol. 2, $n^{\circ}$ 4, pp. 17-52.

KUMM, Mattias. (2012), “Alexy's theory of constitutional rights and the problem of judicial review”, em Matthias Klatt (ed.), Institutionalized reason: the jurisprudence of Robert Alexy. Oxford: Oxford University Press.

LEAL, Fernando. (2017), “Até que ponto é possível legitimar a jurisdição constitucional pela racionalidade? Uma reconstrução da crítica de 'A razão sem voto'”, em Oscar Vilhena Vieira e Rubens Glezer (orgs.), A razão e o voto: diálogos 
constitucionais com Luís Roberto Barroso. Rio de Janeiro: Editora FGV, pp. 108-139.

LEMOS, Leany e Mariana LLANOS. (2013), "Presidential preferences? The Supreme Federal Tribunal nominations in democratic Brazil". Latin American Politics and Society, vol. 55, $\mathrm{n}^{\mathrm{o}}$ 2, pp. 77-105.

MACIEL, Débora e Andrei KOERNER. (2002), "Sentido da judicialização da política: duas análises". Lua Nova, no 57, pp. 113-133.

MANIN, Bernard. (1997), The principles of representative government. Cambridge: Cambridge University Press.

MANIN, Bernard, Adam PRZEWORSKI \& Susan C. STOKES, Susan. (1999), "Introduction" a Adam Przeworski, Susan C. Stokes \& Bernard Manin (eds.), Democracy, accountability, and representation. Cambridge: Cambridge University Press.

MENDES, Conrado Hübner. (2013a), "Political deliberation and constitutional review", em Imer Flores e Kenneth Himma (eds.), Law, liberty, and the rule of law. Dordrecht: Springer Netherlands.

MENDES, Conrado Hübner. (2013b), Constitutional courts and deliberative democracy. Oxford: Oxford University Press.

MENDES, Conrado Hübner. (2015), "Deliberação política e cortes constitucionais", em Adrian Gurza Lavalle, Álvaro de Vita e Cícero Araújo (orgs.), O papel da teoria politica contemporânea: justiça, constituição, democracia e representação. São Paulo: Alameda.

MIGUEL, Luis Felipe. (2014), Democracia e representação: territórios em disputa. São Paulo: Editora Unesp.

MIGUEL, Luis Felipe. (2017), Consenso e conflito na democracia contemporânea. Sáo Paulo: Editora Unesp.

MIGUEL, Luis Felipe. (2018), Dominação e resistência: desafios para uma política emancipatória. São Paulo: Boitempo.

MONTESQUIEU. (1951 [1748]), De l'esprit des lois, em Euvres complètes, t. II. Paris: Gallimard.
NOBRE, Marcos e José Rodrigo RODRIGUEZ. (2011), "Judicialização da política: déficits explicativos e bloqueios normativistas". Novos Estudos, no 91, pp. 5-20.

PAES, Taíse Sossai. (2011), A influência do processo de escolha dos juizes da suprema corte na judicialização da política: uma análise empirica do procedimento da sabatina dos indicados para o Supremo Tribunal Federal. Dissertaçáo de mestrado. Rio de Janeiro: Escola de Direito da FGV.

PEREIRA, Jane. (2017), "O Judiciário pode ser entendido como representante do povo? Um diálogo com 'a razão e o voto' de Luís Roberto Barroso", em Oscar Vilhena Vieira e Rubens Glezer (orgs.), A razão e o voto: diálogos constitucionais com Luis Roberto Barroso. Rio de Janeiro: Editora FGV.

PERES, Paulo e Ernani CARVALHO. (2012), "Religando as arenas institucionais: uma proposta de abordagens multidimensionais nos estudos legislativos". Revista de Sociologia e Politica, vol. 20, no 43, pp. 81-106.

PERUZZOTTI, Enrique e Catalina SMULOVITZ. (2001), "Accountability social: la otra cara del control", em Enrique Peruzzotti e Catalina Smulovitz (eds.), Controlando la politica: ciudadanos y medios en las nuevas democracias latinoamericanas. Buenos Aires: Temas.

PETTIT, Philip. (2013), "Meritocratic representation", em Daniel A. Bell e Chenyang Li (eds.), The East Asian challenge for democracy: political meritocracy in comparative perspective. Cambridge: Cambridge University Press.

PHILLIPS, Anne. (1995), The politics of presence. Oxford: Oxford University Press.

PITKIN, Hanna Fenichel. (1967), The concept of representation. Berkeley: University of California Press.

POGREBINSCHI, Thamy. (2013), Judicialização ou representaçâa? Politica, direito e democracia no Brasil. Rio de Janeiro: Elsevier.

POSNER, Richard. (1996), "Pragmatic adjudication". Cardozo Law Review, vol. 18, no 1, pp. 1-20.

POULANTZAS, Nicos. (2013 [1978]), L'État, le pouvoir, le socialisme. Paris: Les Prairies Ordinaires. 
RANCIÈRE, Jacques. (2005), La haine de la démocratie. Paris: La Fabrique.

RAWLS, John. (2005 [1993]), Political liberalism. Expanded edition. New York: Columbia University Press.

ROSANVALLON, Pierre. (1998), Le peuple introuvable: histoire de la représentation démocratique en France. Pais: Gallimard.

ROSANVALLON, Pierre. (2006), La contre-démocratie: la politique à l'âge de la défiance. Paris: Seuil.

ROSANVALLON, Pierre. (2008), La légitimité démocratique: impartialité, réflexivité, proximité. Paris: Seuil.

ROSANVALLON, Pierre. (2011), La société des égaux. Paris: Seuil.

SAWARD, Michael. (2010), The representative claim. Oxford: Oxford University Press.

SCHAUER, Frederick. (1999), "Talking as a decision procedure”, em Stephen Macedo (ed.), Deliberative politics: essays on Democracy and disagreement. Oxford: Oxford University Press.

SILVA, Virgílio Afonso da. (2013), "Deciding without deliberating". International Journal of Constitutional Law - I-CON, vol. 11, no 3, pp. 557-584.

SOMBRA, Thiago. (2017), "Supremo Tribunal Federal representativo? O impacto das audiências públicas na deliberação". Revista Direito GV, vol. 13, no 1, pp. 236-273.

TATE, C. Neale Torbjon VALLINDER (eds.). (1995), The global expansion of judicial power. New York: New York University Press.

TOCQUEVILLE, Alexis de. (1992 [1835-40]), De la démocratie en Amérique, em Euvres, t. II. Paris: Gallimard.

VIANNA, Luiz Werneck et al. (1999), A judicialização da politica e das relaçóes sociais no Brasil. Rio de Janeiro: Revan.

VIANNA, Luiz Werneck (org.). (2002), A democracia e os três poderes no Brasil. Belo Horizonte: Editora UFMG.

WALDRON, Jeremy. (2016), Political political theory: essays on institutions. Cambridge (MA): Harvard University Press.

YOUNG, Iris Marion. (2000), Inclusion and democracy. Oxford: Oxford University Press.

Outras fontes

STF. Vigésimo Quinto Ag. Reg. na Ação Penal 470/ MG, rel. min. Joaquim Barbosa, red. min. Teori Zavascki, julgado em 18.09.2013.

STF. ADPF no 132, rel. min. Carlos Ayres Britto, julgado em 05.05.2011.

STF. ADI no 3510, rel. min. Carlos Ayres Britto, julgado em 29.05.2008. 


\section{O JUIZ CONSTITUCIONAL ME REPRESENTA? O SUPREMO TRIBUNAL FEDERAL E A REPRESENTAÇÃO ARGUMENTATIVA}

\section{Luis Felipe Miguel, Daniel Bogéa}

Palavras-chave: representação argumentativa, STF, deliberaçáo política

A ideia de representação argumentativa constitui resposta recente à objeçáo democrática ao papel político exercido por tribunais constitucionais. A tese defende que o juiz pode ser concebido como um representante popular, com legitimidade democrática táo sólida quanto os funcionários eleitos do Legislativo ou do Executivo. Cuida-se de movimento que participa do contexto teórico de expansão dos sentidos da representação para instâncias não-eleitorais, como instituiçóes participativas da sociedade civil, conselhos ou movimentos sociais. Neste artigo, colocamos em escrutínio essa construçáo teórica, bem como apontamos os problemas associados à sua incorporação em votos e escritos de ministros do Supremo Tribunal Federal. Concluímos que o argumento padece de fragilidades insuperáveis associadas à crença exacerbada no potencial deliberativo de tribunais, à ausência de mecanismos de aproximação entre pretensos representantes e seus representados e à ausência de mecanismos efetivos de accountability. Além disso, indicamos como a tese pode ser manejada para fins de blindagem discursiva de decisóes politicamente salientes e controversas. Reforçamos, assim, o caráter elitista dessa tentativa, que exacerba o isolamento da corte em relaçáo a seus ditos representados e firma um distanciamento crescente do núcleo essencialmente democrático $\mathrm{da}$ soberania enquanto exercício popular do poder político.

\section{DOES THE CONSTITUTIONAL JUDGE REPRESENTS ME? THE FEDERAL SUPREME COURT AND THE ARGUMENTATIVE REPRESENTATION.}

\author{
Luis Felipe Miguel, Daniel Bogéa
}

Keywords: argumentative representation, Brazilian Supreme Court, political deliberation

The idea of argumentative representation constitutes a recent response to the democratic objection against the political role of constitutional courts. The thesis sustains that the judge can be conceived as a popular representative, holding democratic legitimacy equivalent to elected officials of the legislative or the executive branches. It flourishes in the theoretical context of expansion of the senses of representation to non-electoral instances, such as participatory institutions of civil society, councils, or social movements. In this article, we put this theoretical construction under scrutiny, as well as point out the problems associated with its incorporation in opinions and academic writings of justices of the Brazilian Supreme Court. We argue that the argument is flawed due to an exaggerated belief in the deliberative potential of courts, the absence of approximation mechanisms between would-be representatives and their constituents, and the absence of effective accountability mechanisms. Besides, we point out how the thesis can be used as a rhetoric tool for shielding politically salient and controversial decisions. We thus reinforce the elitist character of this attempt, which exacerbates the isolation of the court from its represented and establishes a growing detachment from the inherently democratic core of sovereignty as a popular exercise of political power.

\section{LE JUGE CONSTITUTIONNEL ME REPRÉSENTE-T-IL? LA COUR SUPRÊME ET LA REPRÉSENTATION ARGUMENTATIVE}

\author{
Luis Felipe Miguel, Daniel Bogéa
}

Mots-clés: Représentation argumentative; Cour suprême brésilienne; Délibération politique.

L'idée d'une représentation argumentative constitue une réponse récente à l'objection démocratique au rôle politique joué par les cours constitutionnelles. La thèse soutient que le juge peut être conçu comme un représentant populaire doté d'une légitimité démocratique aussi solide que les représentants élus du pouvoir législatif ou les fonctionnaires du pouvoir exécutif. C'est un mouvement qui participe du contexte théorique d'élargissement du sens de la représentation à des instances non électorales, telles que des institutions participatives de la société civile, des conseils ou des mouvements sociaux. Dans cet article, nous examinons attentivement cette construction théorique et soulignons les problèmes liés à son incorporation dans les votes et les écrits des ministres de la Cour suprême brésilienne. Nous concluons que l'argument souffre de faiblesses insurmontables liées à la croyance exagérée dans le potentiel délibératif des tribunaux, à l'absence de mécanismes de rapprochement entre les représentants potentiels et leurs représentés et à l'absence de mécanismes efficaces de responsabilité. En outre, nous indiquons de quelle manière la thèse peut être gérée dans le but de protéger de manière discursive les décisions controversées et d'importance politique. Ainsi, nous renforçons le caractère élitiste de cette tentative, qui exacerbe l'isolement de la cour par rapport à ses représentés présumés et établit un détachement croissant du noyau essentiellement démocratique de la souveraineté en tant qu' exercice populaire du pouvoir politique. 